\title{
The Immunization Status Evaluation of the Children Hospitalized
}

\author{
Burcu Doğan, ${ }^{1}$ Yasemin Akın² \\ 'Department of Family Medicine, Sakarya Training and Research Hospital, Sakarya, Turkey \\ ${ }^{2}$ Department of Pediatric Health and Diseases Clinics, Kartal Dr. Lütfi Kırdar Training and Research Hospital,
} Istanbul, Turkey

\section{ABSTRACT}

Objectives: In our study, we aimed to identify the vaccination rates in hospitalized children by analyzing their immunization records and the factors that affect vaccination status.

Methods: In our study, we have analyzed cases 3-48 months of age old who were hospitalized between 20062008 in Kartal Dr. Lütfi Kırdar Training and Research Hospital, Pediatric Health and Diseases Clinics. The immunization registration forms saved by the parents were inspected and saved in the questionnaire sheets.

Results: The study group included 218 (43.4\%) female and 284 (56.6\%) male, total 502 cases while mean birth weight of the children was $3067.0 \pm 690.3$ grams. Mean duration of exclusive breastfeeding was found 3.5 (1.020.0) months. Vaccination rate analysis of the 502 cases, 379 (75.5\%) cases was fully vaccinated, whereas 123 (24.5\%) cases children received incomplete vaccination.

Conclusion: We have encountered inadequate childhood vaccination rates in hospitalized children.

Keywords: Children, immunization, vaccination

\section{INTRODUCTION}

Vaccination is the most effective procedure in protecting pediatric health and preventing contagious diseases. The follow-up process of childhood vaccination is one of the essential tasks of primary healthcare providers. Some vaccines not only prevent diseases but also contribute to the immunization of other subjects. It is estimated that approximately 2 to 3 million deaths can be prevented by vaccination every year. ${ }^{[1,2]}$ Vaccination is very effective in the control and eradication of contagious diseases. ${ }^{[3]}$ By the eradication of smallpox, the World Health Organization initiated the Expanded Programme on Immunization in 1974 and the lives of millions of children were saved thanks to implemented vaccines from that date until today. ${ }^{[4,5]}$ Approximately $70 \%$ of all pediatric deaths below five years of age arise from contagious diseases in developing countries. Pediatric can be reduced by the effective implementation of the available vaccines. ${ }^{[6]}$ Substantial changes have been made in the Turkish National Childhood Immunization Schedule by the Turkish Ministry of Health. For instance, H. Influenza Type b (HIB) and combined vaccine of Measles-Mumps-Rubella (MMR) were added to the Turkish National Childhood Immunization Schedule in 2006, as well as the addition of Pneumococcal Conjugate Vaccines (PCV) to the schedule in 2009. ${ }^{[7]}$ After these recent annexations, implementation of Hepatitis $A$ vaccination doses at $18^{\text {th }}$ and $24^{\text {th }}$ months and Varicella vaccine dose at $12^{\text {th }}$ month were included in the 2020 National Childhood Immunization Schedule of Turkey.
(C) Copyright 2020 by Anatolian Journal of Family Medicine Available online at www.anatoljfm.org OPEN ACCESS 
Booster dose of Adult Diphtheria-Tetanus Vaccine (Td) was replaced by a quadrivalent version as Diphtheria, acellular Pertussis, Tetanus, Inactivated Polio Vaccination including Type B (DaPT-IPV). The recommendable vaccinations in the childhood period may include Rotavirus Vaccination at $1^{\text {st }}, 2^{\text {nd }}$ and $4^{\text {th }}$ months, Human Papillomavirus Vaccination between nine to $18^{\text {th }}$ years of age; annual implementation Inactivated Influenza Vaccination and Meningococcal Vaccination starting after $6^{\text {th }}$ month of age. ${ }^{[8]}$

The present study aims to evaluate vaccination rates in hospitalized children and the factors affecting them.

\section{METHOD}

In our study, we analyzed 502 cases aged between 3-48 months of age hospitalized between 2006-2008 in the Kartal Dr. Lütfi Kırdar Training and Research Hospital, Pediatric Health and Diseases Clinics. We questioned the participants and inspected the immunization registration forms saved by the parents to record in the questionnaire forms.

The questionnaire forms included data, such as vaccination status of the cases, healthcare facility that performed vaccination (until that date), frequency of hospitalizations, birthplace, birth weight, duration of exclusive breastfeeding, a healthcare facility that performed postpartum follow-up, number of siblings, maternal and parental educational status, employment status, income level, current residence and migration history if available. These collected data were saved in the questionnaire forms following inspection of their immunization records.

According to Turkish Ministry of Health, Childhood Immunization Schedule 2009; Bacille-Calmette-Guerin vaccine $(B C G)$ end of $2^{\text {nd }}$ month; Hepatitis $B$ vaccine (HBV) $0^{\text {th }}, 1^{\text {st }}$ and $6^{\text {th }}$ months; DTaP-IPV-HIB vaccine $2^{\text {nd }}, 4^{\text {th }}, 6^{\text {th }}$ months, booster dose at $18^{\text {th }}-24^{\text {th }}$ month; Oral Polio vaccine (OPV) 6th month, 18-24 month, $1^{\text {st }}$ year of primary school; PCVvaccine $2^{\text {th }}, 4^{\text {th }}, 6^{\text {th }}, 12^{\text {th }}$ months; MMR vaccine $12^{\text {th }}$ month $/ 1^{\text {st }}$ year of primary school; $T d$ vaccine $1^{\text {st }}$ and $8^{\text {th }}$ years of primary school are applied. ${ }^{[7]}$

Immunization registration forms, saved by parents, were meticulously inspected to ensure the reliability of the statements about the vaccination records. In total, 550 mothers and first degreerelatives of the patients were interviewed. This questionnaire was based on instructions on vaccines and vaccination schedule. The consents were taken from their family members for their participation in the questionnaire. Forty-eight of the cases were excluded from this study since they could not complete the questionnaire due to various reasons. The patients and the patient relatives offered to participate in thisstudy were randomly selected. Age, num- ber of the children, income level or another criterion were not considered in the selection of the participants. The patient relatives were interviewed in face-to-face questionnaire and the answers were recorded by an identical interviewer physician. The study data were obtained by the questionnaire composed of multiple-choice and open-ended questions intended to identify the sociodemographic characteristics and assess the information about vaccination. The questionnaire data were evaluated in accordance with the National Childhood Immunization Schedule of the Ministry of Health.

All the collected data were analyzed using SPSS Version 13.5 Statistical Software. Descriptive statistical methods frequency, percentage, mean, standard deviation, median, minimum and maximum were used while evaluating the study data.

\section{RESULTS}

Our study group included 502 children, 218 (43.4\%) female and $284(56.6 \%)$ male, who were hospitalized for treatment. Mean birth weight was found $3067.0 \pm 690.3$ grams. Mean duration of exclusive breastfeeding was calculated as 3.5 (1.0-20.0) months. Of the cases, 203 (40.4\%) and 299 (59.6\%) were determined as vaccinated before and after 2006 in accordance with the Immunization Schedule of the Ministry of Health, respectively. The demographic information, such as birth-related data, birthplace, the facility that performed the vaccination follow-up and families data were presented in Table 1.

In our study, 394 (78.5\%) of the patients were resident in Kartal county where our hospital was administratively bounded, whereas 29 (5.8\%) and $56(15.8 \%)$ were residents in the other counties of Istanbul and out of the province, respectively. Of the cases, $24(4.8 \%), 4(0.8 \%), 69(13.7 \%)$, 197 (39.2\%), 4 (0.8\%), 185 (36.9\%), and 18 (3.6\%) originated from respectively Marmara, Aegean, Central Anatolia, Blacksea, Mediterranean, Eastern and South-Eastern Anatolian Regions, while $1(0.2 \%)$ case was originated from a foreign country. The analysis of the concerning hospitalizations revealed that 426 (84.9\%), 49 (9.8\%) and 25 (5.4\%) children were hospitalized for at least 1-2, 3-4 and more than four times, respectively.

The vaccination coverage rates at the time of first, second, third, fourth ( 410 cases to be vaccinated), fifth ( 283 cases to be vaccinated) and sixth (184 cases to be vaccinated) admission of the children to the healthcare facilities were 481 (95.8\%), 440 (87.6\%), 417 (83.1\%), 340 (82.9\%), 243 (85.9\%) and $153(83.2 \%)$ whereas incomplete vaccination rates were encountered 21 (4.2\%), 62 (12.4\%), 85 (17.1\%), 70 (17.1\%), 40 (14.1\%) and 31 (16.8\%), respectively. Based on total cases, 
Table 1. Demographic features of the cases and family

n (\%)

Birth knowledge of cases

Preterm

$66(13.1)$

Term

Postterm

$434(86.5)$

$2(0.4)$

Where observed children

Not be followed

$49(9.7)$

Primary healthcare center

Maternal child health and family planning clinic

Public hospital

Training and research hospital

University hospital

Private hospital

Birthplace of children

At home

Primary health care provider

$2^{\text {nd }}$ level health institution

$3^{\text {rd }}$ level health institution

Private hospital

Training and research hospital

University hospital

Education level of the mother

Illiterate

Primary school

Middle school

High school

University

Education level of father

Illiterate

Primary school

Middle school

High school

College

University

Working status of the mother

Working

Not working

Economic status of the family

Below minimum wage

Minimum wage

Above minimum wage

Chronic disease in children

Yes

179 (35.7)

No

$323(64.3)$

Total

$502(100.0)$
$379(75.5 \%)$ cases received full vaccination, whereas incomplete vaccination was detected in 123 (24.5\%) cases. The vaccination frequency of the children between the years 2006-2008 in accordance with the National Childhood Immunization Schedule is shown in the Table 2. The vaccination evaluation of the cases at each visit to get vaccinated in the healthcare center is given in Table 3.

\section{DISCUSSION}

We have determined in our study that $75.5 \%$ and $24.5 \%$ of the hospitalized children were fully and incompletely vaccinated between 2006-2008 in the Kartal region of Istanbul, respectively. Some other studies carried out in Konya and Adana provinces have encountered a vaccination coverage rate of $82 \% .{ }^{[9]}$ It was reported in 2003 in İzmir that $97.1 \%$ and $2.9 \%$ of the children were fully and incompletely vaccinated, respectively. ${ }^{[10]}$ The rates of the fully, incompletely and unvaccinated hospitalized children in The Haydarpaşa Numune Hospital were in 2006 were found 66.5\%, 29.6\% and $3.9 \%$, respectively. ${ }^{[1]]}$ The vaccination coverage rate of the children was determined as $98.3 \%$ in 2006 in Eskişehir. ${ }^{[12]}$ In $2007,81.1 \%$ and $18.9 \%$ of the children were identified to be fully and incompletely vaccinated in Yalova, respectively. ${ }^{[13]} \mathrm{A}$ study conducted in Widwest has demonstrated that none of the vaccines that should be administered until two years of childhood were applied in $47 \%$ of the children. ${ }^{[14]}$ Tifft et al. have reported that incomplete vaccination rate was $19 \%$ in the hospitalized preschool children and that $53 \%$ of those children with incomplete vaccination at time of discharge still remained incompletely vaccinated. ${ }^{[15]}$

It has been reported according to The Turkey Demographic and Health Survey (TDHS) 2003 data; 54\%, 43\% and 3\% of the children were fully, incompletely and unvaccinated, respectively. The vaccination rate was found lower in the residents of Eastern Anatolia Region than other regions. ${ }^{[16]}$ According to the 2008 TDHS outcomes, the rates of fully and unvaccinated 0-35-month-old children were reported as $70.5 \%$ and $2.6 \%$, respectively. ${ }^{[17]}$ Our study group is composed of hospitalized children. Thus, vaccination coverage rate may be higher compared with TDHS data that represent general society data. In the light of the 2008 TDHS data, $80 \%$ of the children living in urban settlement were fully vaccinated, whereas that rate decreases to $67 \%$ in the children living in the rural settlement. The vaccination certificate is present in $63 \%$ of the children living in the south of Turkey, whereas $80 \%$ of the children living in the western region have a vaccination certificate. Vaccination rates of female and male children are $79 \%$ and $75 \%$, respectively. Vaccine coverage rate of the children in the first birth rank is $81 \%$, whereas that rate decreases to $55 \%$ in the children 
Table 2. Vaccination dates and frequency of children hospitalized the National Childhood Immunization Program

\begin{tabular}{|c|c|c|c|c|c|c|c|c|}
\hline & 2002 & 2003 & 2004 & 2005 & 2006 & 2007 & 2008 & Total \\
\hline \multicolumn{9}{|l|}{ BCG } \\
\hline+ & $6(100.0)$ & $32(82.1)$ & 43 (93.5) & $107(95.5)$ & $122(80.3)$ & $64(90.1)$ & 75 (98.7) & 449 (89.4) \\
\hline- & $0(0.0)$ & 7 (17.9) & $3(6.5)$ & $5(4.5)$ & 30 (19.7) & 7 (9.9) & $1(1.3)$ & $53(10.6)$ \\
\hline \multicolumn{9}{|c|}{ 1.Dose DaPT } \\
\hline+ & $6(100.0)$ & $32(82.1)$ & $42(91.3)$ & $106(94.6)$ & 121 (79.6) & $64(90.1)$ & 74 (97.4) & 445 (88.6) \\
\hline- & $0(0.0)$ & 7 (17.9) & $4(\% 8.7)$ & $6(5.4)$ & $31(20.4)$ & $7(9.9)$ & $2(2.6)$ & $57(11.4)$ \\
\hline \multicolumn{9}{|c|}{ 1.Dose Polio } \\
\hline+ & $6(100.0)$ & $32(82.1)$ & 42 (91.3) & $106(94.2)$ & $121(79.6)$ & $64(90.1)$ & 74 (97.4) & 445 (88.6) \\
\hline- & $0(0.0)$ & 7 (17.9) & $4(8.7)$ & $6(5.8)$ & $31(20.4)$ & $7(9.9)$ & $2(2.6)$ & $57(11.4)$ \\
\hline \multicolumn{9}{|c|}{ 1.Dose HBV } \\
\hline+ & $6(100.0)$ & 34 (87.2) & 44 (95.7) & 109 (97.3) & $143(94.1)$ & 69 (97.2) & 75 (98.7) & 480 (95.6) \\
\hline- & $0(0.0)$ & $5(12.8)$ & $2(4.3)$ & $3(2.7)$ & $9(5.9)$ & $2(2.8)$ & $1(1.3)$ & $22(4.4)$ \\
\hline \multicolumn{9}{|c|}{ 1.Dose HIB } \\
\hline+ & $6(100.0)$ & 34 (87.2) & 44 (95.7) & $109(97.3)$ & $143(94.1)$ & 69 (97.2) & 75 (98.7) & 480 (95.6) \\
\hline- & $0(0.0)$ & $0(0.0)$ & $0(0.0)$ & $1(3.2)$ & $31(20.4)$ & $7(9.9)$ & $2(2.6)$ & 41 (11.9) \\
\hline \multicolumn{9}{|c|}{ Measles } \\
\hline+ & $6(100.0)$ & $31(79.5)$ & $37(82.2)$ & $2(100.0)$ & - & - & - & 76 (82.6) \\
\hline- & $0(0.0)$ & $8(20.5)$ & $8(17.8)$ & $0(0.0)$ & - & - & - & $16(17.4)$ \\
\hline \multicolumn{9}{|c|}{ 2. Dose DaPT } \\
\hline+ & $6(100.0)$ & $32(82.1)$ & 40 (88.9) & $99(88.4)$ & $110(72.4)$ & 62 (88.6) & $47(87)$ & 396 (82.7) \\
\hline- & $0(0.0)$ & 7 (17.9) & $6(11.1)$ & $13(11.6)$ & $42(27.6)$ & $8(11.4)$ & $7(13)$ & $83(17.3)$ \\
\hline \multicolumn{9}{|c|}{ 2. Dose Polio } \\
\hline+ & $6(100.0)$ & $32(82.1)$ & 40 (88.9) & $99(88.4)$ & $110(72.4)$ & 62 (88.6) & 47 (87.0) & 396 (82.7) \\
\hline- & $0(0.0)$ & $7(17.9)$ & $6(11.1)$ & $13(11.6)$ & 42 (27.6) & $8(11.4)$ & $7(13.0)$ & $83(27.3)$ \\
\hline \multicolumn{9}{|c|}{ 2. Dose HBV } \\
\hline+ & $6(100.0)$ & $32(82.1)$ & 41 (89.1) & $103(92.0)$ & $119(78.3)$ & $63(90.0)$ & 72 (94.7) & $437(87.1)$ \\
\hline- & $0(0.0)$ & $7(17.9)$ & $5(10.9)$ & $9(8.0)$ & $33(21.7)$ & $7(10.0)$ & $4(5.3)$ & 65 (12.9) \\
\hline \multicolumn{9}{|c|}{ 2. Dose HIB } \\
\hline+ & $1(100.0)$ & $8(100.0)$ & $5(100.0)$ & $27(87.1)$ & $110(72.4)$ & 62 (88.6) & 47 (87.0) & $260(81.0)$ \\
\hline- & $0(0.0)$ & $0(0.0)$ & $0(0.0)$ & 4 (12.9) & 42 (27.6) & $8(11.4)$ & $7(13.0)$ & $61(19.0)$ \\
\hline \multicolumn{9}{|c|}{ MMR } \\
\hline+ & $1(100.0)$ & $5(100.0)$ & $4(100.0)$ & $49(84.5)$ & $36(81.8)$ & $24(92.3)$ & 1 (100.0) & $120(86.3)$ \\
\hline- & $0(0.0)$ & $0(0.0)$ & $0(0.0)$ & $9(15.5)$ & $8(18.2)$ & $2(7.7)$ & $0(0.0)$ & 19 (13.7) \\
\hline \multicolumn{9}{|c|}{ 3. Dose DaPT } \\
\hline+ & $6(100.0)$ & 31 (79.5) & 39 (84.8) & $89(80.2)$ & $87(73.1)$ & $50(82.0)$ & $28(93.3)$ & $330(80.1)$ \\
\hline- & $0(0.0)$ & $8(20.5)$ & $7(15.2)$ & $22(19.8)$ & 32 (26.9) & $11(18.0)$ & $2(6.7)$ & 82 (19.9) \\
\hline \multicolumn{9}{|c|}{ 3. Dose Polio } \\
\hline+ & $6(100.0)$ & $31(79.5)$ & $39(84.8)$ & $89(80.2)$ & $87(73.1)$ & $50(82.0)$ & $28(93.3)$ & $330(80.1)$ \\
\hline- & $0(0.0)$ & $8(20.5)$ & $7(15.2)$ & $22(19.8)$ & 32 (26.9) & 11 (18.0) & $2(6.7)$ & 82 (19.9) \\
\hline \multicolumn{9}{|c|}{ 3. Dose HBV } \\
\hline+ & $6(100.0)$ & 31 (79.5) & $39(84.8)$ & $70(84.3)$ & $52(85.2)$ & 34 (91.9) & 28 (93.3) & $260(86.1)$ \\
\hline- & $0(0.0)$ & $8(20.5)$ & $7(15.2)$ & $13(15.7)$ & $9(14.8)$ & $3(8.1)$ & $2(6.7)$ & 42 (13.9) \\
\hline \multicolumn{9}{|c|}{ 3. Dose HIB } \\
\hline+ & $1(100.0)$ & $8(100.0)$ & $5(100.0)$ & $23(74.2)$ & 87 (73.1) & $50(82.0)$ & $28(93.3)$ & $202(79.2)$ \\
\hline- & $0(0.0)$ & $0(0.0)$ & $0(0.0)$ & $8(25.8)$ & 32 (26.9) & $11(18.0)$ & $2(6.7)$ & $53(20.8)$ \\
\hline
\end{tabular}




\begin{tabular}{|c|c|c|c|c|c|c|c|c|}
\hline & 2002 & 2003 & 2004 & 2005 & 2006 & 2007 & 2008 & Total \\
\hline+ & $6(100.0)$ & 30 (76.9) & $31(72.1)$ & $23(82.1)$ & $22(84.6)$ & 7 (87.5) & - & $119(79.3)$ \\
\hline- & $0(0.0)$ & $9(23.1)$ & $12(27.9)$ & $5(17.9)$ & $4(15.4)$ & $1(12.5)$ & - & $31(20.7)$ \\
\hline- & $0(0.0)$ & $9(23.1)$ & $13(30.2)$ & $5(17.9)$ & $4(15.4)$ & $1(12.5)$ & - & $32(21.3)$ \\
\hline \multicolumn{9}{|c|}{ 4. Dose HIB } \\
\hline+ & $1(100.0)$ & $8(100.0)$ & $3(100.0)$ & 11 (78.6) & $22(88.0)$ & 7 (87.5) & - & $52(88.1)$ \\
\hline- & $0(0.0)$ & $0(0.0)$ & $0(0.0)$ & $3(21.4)$ & $3(12.0)$ & $1(12.5)$ & - & 7 (11.9) \\
\hline
\end{tabular}

in the sixth or higher birth rank. ${ }^{[17]}$ Although vaccine rate of the children in the first dose is $94.0 \%$ in female and $97.2 \%$ in male, vaccine rate of the children in the sixth dose is $84.1 \%$ in female and $79.4 \%$ in male. According to the 2003 TDHS data, vaccination coverage rate of the children born to illiterate mothers is $26 \%$, whereas that rate is $69 \%$ in the children born to at least high school graduate mothers. ${ }^{[16]}$ In our study, deficiency rates $14.1 \%$ to $37.5 \%$ among illiterate mothers, $0.3 \%$ to $17.6 \%$ among primary school graduate mothers, $0.0 \%$ to $16.7 \%$ among middle school graduate mothers also, $0.0 \%$ and $14.8 \%$ among university graduate mothers. Some research carried out in England determined that unvaccination rate was high in the children born to high-education level mothers. It was expressed that this situation was caused by anti-vaccination propaganda by English Media. Their findings suggest that vaccination should be universal and such declines in the vaccination rates may be resulting from simple and resolvable reasons and preventable by adequate communication and monitoring. ${ }^{[18]}$ A study conducted in Malatya showed that there was no significant difference between male and female children concerning vaccination status. No statistically significant correlation was determined between maternal educational level and vaccination of their babies; however, immunization rates were found to increase as the maternal educational level increased. The families' socioeconomic distribution in this research revealed that $48.8 \%, 37.3 \%$ and $13.9 \%$ of the participant families were from the lower, middle, and upper socioeconomic status, respectively. ${ }^{[19]}$ On the other side, $11 \%, 52.2 \%$ and $36.9 \%$ of the participant families had income levels below, equal and over the minimum wage, respectively. A study carried out between 1998-2001 in the rural area of Şanlıurfa Province has demonstrated that vaccination coverage, incomplete vaccination and unvaccina- tion rates were $17.9 \%, 60.7 \%$ and $14.3 \%$ in the $2-23$ months old children, respectively. Vaccination rates were found to decrease as the number of the children increased in the families. This study reported that vaccination rate was low in the children born to illiterate mothers and the vaccination rate increased as the educational level increased. ${ }^{[20]} \mathrm{A}$ study carried out in 2007 in Haydarparşa Numune Hospital revealed encountered that gender, hospitalization and social insurance of the family had no effect on the vaccination rates. This study reported that the vaccination rate decreased as the number of the children of the family increased. It was detected that maternal illiteracy negatively affected vaccination rate and that $85.8 \%$ of the families received vaccination service in primary healthcare center and Maternal and Infant Healthcare Center for their children. ${ }^{[21]}$ In our study, we determined a higher rate of incomplete vaccination at the first hospitalization of the unfollowed cases who were not followed-up by a primary healthcare center and Maternal and Infant Healthcare Center, which shows the importance of primary healthcare centers and Maternal and Infant Healthcare Centers in childhood vaccination follow-up. An analysis of children with incomplete vaccination administered in 2007 in Diyarbakır suggested that $62.3 \%$ and $13.4 \%$ of respectively mothers and fathers of the children were illiterate and that the educational level of the parents affected vaccination rates of the children. A low level of socioeconomic status was found to reduce vaccination levels. The results of this study showed that to be a child in the $8^{\text {th }}$ birth rank increased the risk for incomplete vaccination 6.07-fold compared with the child in the first birth rank. ${ }^{[22]}$ It was determined that number of the children in the family, residential duration at the stated address, education and financial level of the mother and father, suburban life and history if migration are the risk factors for 


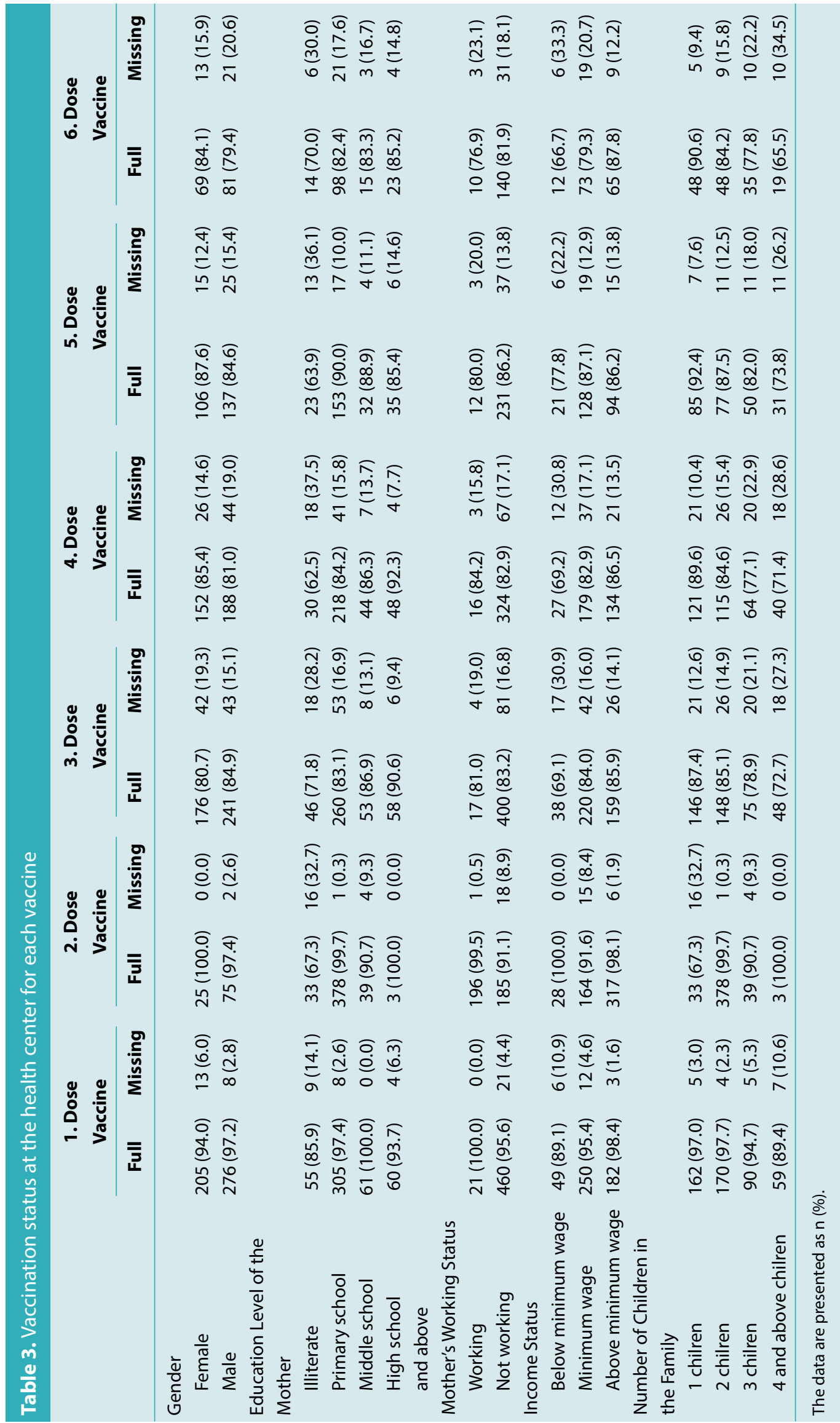


incomplete vaccination. ${ }^{[11,21]}$ In 2017, full immunization rate was found $100 \%$ in the children followed-up by a Maternal and Infant Healthcare Center, which was administratively bounded to Zonguldak province. ${ }^{[23]}$ This outcome suggested us that national immunization programmes established and continued by the Ministry of Health by updates since 2008 and switching to Family Medicine System may have provided positive effects.

\section{CONCLUSION}

The vaccination rates were affected by maternal education status, the income level of the family, number of the children in the family, the institutions that followed-up the vaccination schedule of the children, presence of a chronic disease, family origin and the years of vaccination follow-up.

Healthcare professionals and parents should be aware of their responsibilities in the implementation of the vaccines. The importance of vaccination coverage concerning the protection of the children from the contagious infectious diseases is known. The positive effects of the immunization programmes continued by the Ministry of Health by updates have been reported. The primary rationale of our study was to evaluate the childhood vaccination rates and effective factors on childhood vaccination rate while the secondary rationale of the study was to increase the awareness of the families on this issue by attracting their attention. Similar and further studies are needed to emphasize the importance of childhood vaccinations and to raise the awareness of the parents.

\section{Disclosures}

Peer-review: Externally peer-reviewed.

Conflict of Interest: None declared.

Ethics Committee Approval: This study was produced from the thesis, which was performed Istanbul Kartal Dr. Lütfi Kırdar Training and Research Hospital between 2006-2008, by completing the local permission procedures of Kartal Dr. Lütfi Kırdar Training and Research Hospital as of the date of the thesis study. The questionnaire forms were filled by obtaining verbal consent from the parents of hospitalized children.

Authorship Contributions: Concept - B.D.; Design - B.D., Y.A.; Supervision - Y.A.; Materials - B.D.; Data collection \&/or processing - B.D.; Analysis and/or interpretation - B.D.; Literature search - B.D.; Writing - B.D.; Critical review - Y.A.

\section{REFERENCES}

1. Kutlu R. Çocukluk Çağı Aşıları. Türkiye Klinikleri J FamMedSpecial Topics 2017;8(5):311-8.

2. Akşit S. Çocukluk çağında aşı takvimi. Türk Pediatri Arşivi 2007;42:26-35.
3. World Health Organization. Health topics, Immunization. Available at: https://www.who.int/topics/immunization/en/. Accessed Jul 17, 2020.

4. Egemen A, Akşit S. Bağışıklamanın İmmünolojik Temelleri. T.C. Sağlık Bakanlığı, Temel Sağlık Hizmetleri Genel Müdürlüğü ve Sağlık Projesi Genel Koordinatörlüğü. Ankara: Bizim Büro Basımevi; 1998. p. 1-20.

5. Özmert EN. Dünya'da Aşılama ve Aşı Takvimleri. Turkiye Klinikleri Pediatric Sciences-Special Topics2007;3(11):8-14.

6. Shann F, Steinhoff MC. Vaccines for children in rich and poor countries. Lancet1999;354:7-11.

7. T.C.Sağlık Bakanlığı Genişletilmiş Bağışıklama Programı Genelgesi (2009) Available at: https://www.saglik.gov.tr/TR,11137/ genisletilmis-bagisiklama-programi-genelgesi-2009.html. Accessed Jul 17, 2020.

8. T.C. Sağlık Bakanlığı Kamu Hastaneleri Genel Müdürlüğü Sağlık Hizmetleri Daire Başkanlığı, Genişletilmiş Bağışıklama Programı Genelgesi. Available at: https://khgmsaglikhizmetleridb.saglik.gov.tr/TR,42937/genisletilmis-bagisiklamaprogrami-genelgesi.html. Accessed Jul 17, 2020.

9. Bilir GS, Özkozacı T, Günaydın C. Annelerin aşı bilgi düzeyleri, çocukların aşılama durumu ve bunları etkileyen faktörler. Available at: www.millipediatri.org.tr/bildiriler/PP-065.htm. Accessed Jul 17, 2020.

10. Yaprak I, Halıcıoğlu O, Kurun Ü, Okçu SÇ, Akduman I. İki-Altı Yaş Çocuklarda Aşılanma Durumu ve Etkileyen Risk Faktörleri. İzmir Tepecik Hastanesi Dergisi 2005;15(1):13-21.

11. Göksügür SB. Annelerin aşı bilgi düzeyleri, aşılamayı etkileyen faktörler. Uzmanlık Tezi. İstanbul, 2006. Available at: http:// www.istanbulsaglik.gov.tr/w/tez/pdf/cocuk_sagligi/dr_sevil_bilir_goksugur.pdf. Accessed Jul 17, 2020.

12. Derince D. Eskişehir İli İnönü Merkez Sağlık Ocağı Bölgesinde 0-59 Aylık Çocuğu Olan Annelerin Bağışıklama Konusundaki Bilgi, Tutum ve Davranışlarının Değerlendirilmesi, Yükseklisans tezi; Afyonkarahisar, 2006. Availableat: https://acikerisim. aku.edu.tr/xmlui/bitstream/handle/11630/3879/192494. pdf?sequence=1\&isAllowed=y. Accessed Jul 17, 2020.

13. Babadağlı F, Gökçay G, Ertem HV, Bulut A. Yalova Devlet Hastanesine Başvuran 12-36 Ay Arası Çocuklarda Aşı Eksiklikleri ve Bunu Etkileyen Faktörler. Çocuk Dergisi 2007;7(4):233-9.

14. Bates AS, Wolinsky PHD. Personal, financialandstructuralbarrierstoimmunization in socioeconomicallydisadvantaged urban children. Pediatrics 1998;101 (4 part I):591-6.

15. Tifft CJ, Lederman HM. Immunizationstatus of hospitalisedpreschoolagechildren. Am J Dis Child 1988;142:719-20.

16. Çocuk Sağlığı, Türkiye Nüfus ve Sağlık Arastırması. Hacettepe Üniversitesi Nüfus Etüdleri Enstitüsü 2003;11:134-40.Available at: http://www.hips.hacettepe.edu.tr/pdf/TNSA2003AnaRapor.pdf. Accessed Jul 17, 2020.

17. Tezcan S, Kurtuluş-Yiğit E, Tunçkanat FH, Çocuk Sağlığı, Türkiye Nüfus ve Sağlık Arastırması. Hacettepe Üniversitesi Nüfus Etüdleri Enstitüsü 2008.;11:159-69. Availableat: http://www. hips.hacettepe.edu.tr/TNSA2008-AnaRapor.pdf. Accessed Jul 17, 2020.

18. Millward G. Vaccinating Britain: Massvaccinationandthepub- 
lic since the Second World War. Manchester (UK): Manchester UniversityPress; 2019. (cited 2020 April 04) Available at: https://www.ncbi.nlm.nih.gov/books/NBK545995/. Accessed Jul 17, 2020.

19. Ok Ş, Pehlivan E, Geçkil E. Malatya il merkezindeki 12 aylık bebeklerin bağışıklama durumu. Atatürk Üniversitesi Hemşirelik Yüksek Okulu Dergisi 2004;7(1):50-60.

20. Kurçer MA, Şimşek Z, Solmaz A, Dedeoğlu Y, Gülel R. Şanlıurfa Harrankapı sağlık ocağı bölgesi'nde $0-2$ yaş çocuk ve gebelerde aşılanma oranları ve aşılanmada sorunlar. Harran Üniversitesi Tıp Fakültesi Dergisi 2005;2:10-5.

21. Mengüç Y. 6 ay- 24 ay arasındaki çocuklarda aşılanma oranları ve ailelerin sosyo demografik verileri. Uzmanlık Tezi. İstanbul.
Availableat: http://www.istanbulsaglik.gov.tr/w/tez/pdf/aile_ hekimligi/dr_yavuz_menguc.pdf. Accessed Jul 17, 2020.

22. Yiğitalp G, Ertem M. Diyarbakır ilinde 0-12 aylık çocukların aşıya devamsızlık nedenleri, Diyarbakır. Availableat: https:// www.akademikbilgisistemi.com/akademisyen/prof-dr-meliksah-ertem/4/. Accessed Jul 17, 2020.

23. Kürtüncü M, Alkan I, Bahadır Ö, Arslan N. Zonguldak'ın kırsal bir bölgesinde yaşayan çocukların aşılanma durumu hakkındaki annelerin bilgi düzeyleri, Electronic Journal of VocationalColleges. Availableat: https://www.researchgate.net/ profile/Oezguer_Bahadir/publication/337569852_Electronic_Journal_of_Vocational_Colleges-. Accessed Jul 17, 2020. 